\title{
Dynamic Forces in Unstable Cutting during Turning Operation
}

Pavel Bach, Miloš Poláček, Petr Chvojka, Jiří Drobílek

Faculty of Mechanical Engineering, Czech Technical University in Prague, Research Center of Manufacturing Technology (RCMT). Horska 3, 14900 Prague. Czech Republic. E-mail: p.bach@rcmt.cvut.cz

The theory of self-excited vibrations (chatter) in machining, formulated in the 1950s, assumes a single cutting force. The assumption of a single cutting force in unstable cutting is commonly accepted to this day. In this paper, we will present the reader and listener with a hypothesis concerning the effect of several dynamic forces acting on unstable cutting during turning operations. A new form of the force model will be presented. The calculation of stability limit as well as accuracy of the prediction of stable cutting conditions depends on this model. The validity of the hypothesis has yet to be demonstrated. Preparations for verification experiments have been under way for approximately one year and the experiments will start this year (2014). The hypothesis is based on the results of some earlier measurements of the dynamic forces by foreign authors as well as one of the authors of this paper, Miloš Poláček.

Keywords: Chatter, Complex Dynamic Cutting Forces

\section{Acknowledgement}

The research has been funded within the framework of the grant TE01020075 Competence Centre - Manufacturing Technology of the Technology Agency of the Czech Republic.

\section{References}

[1] POLÁČEK, M. (1955). Výpočet stability rámu obráběcího stroje. Kandidátská disertační práce (Ph.D. Thesis), ČVUT v Praze. (Odvození principu polohové vazby a regenerativního principu postupného rozkmitávání).

[2] TLUSTÝ, J., POLÁČEK M. (1963). The Stability of the Machine-Tool against Self-Excited Vibration in Machining. The IRPE Conference, ASME, Pittsburgh.

[3] ALtintAS, Y., BUDAK, E. (1995). Analytical Prediction of Stability Lobes in Milling. Annals of CIRP, 1, 44, pp. $357-362$.

[4] ALTINTAS, Y., EYNIAN, M., ONOZUKA, H. (2008). Identification of Dynamic Cutting Force Coefficients and Chatter Stability with Process Damping. CIRP Annals MT, 1, 57, pp. 371-374.

[5] TRMAL, G. J., BACH, P. (2008). Economy of Titanium Machining. Proceedings of the conference MATAR 2008. Praha: pp. 60-66.

[6] BACH, P., ZEMAN, P., VÁŇA, J., KOUKOL, V. (2009). Titanium Machining. Proceedings of the conference HSS Forum. Aachen.

[7] MALÝ, J., ZEMAN, P., MÁDL J. (2009). Vliv řezného prostředí a řezných podmínek na velikost teplot a zbytkového napětí v obrobeném povrchu prri frézování slitiny titanu Ti6Al4V. Manufacturing Technology, Plzeň: [s.n.], pp. 9. ISBN 978-80-7043-7.

[8] VÁŇA, J., ZEMAN, P. (2009). Trvanlivosti břitů HSS nástrojů nové generace při frézování slitiny Ti6Al4V. Manufacturing Technology, Plzeň, pp. 9. ISBN 978-80-7043-7.

[9] BACH, P., (2009). HSS nástroje z PM ocelí pro výkonné a ekonomické frézování titanových slitin, Machining\&Tooling, No.1.

[10] EYNIAN, M., ALTINTAS, Y. (2010). Analytical Chatter Stability of Milling with Rotating Cutter Dynamics at Process Damping Speeds. Journal of Manufacturing Science and Engineering, April, 2, 132.

[11] EYNIAN, M. (2010). Chatter Stability of Turning and Milling with Process Damping. A Thesis for the Degree of $P h . D$., University of British Columbia.

[12] TLUSTY, J. (1978). Analysis of the Research in Cutting Dynamics. Annals of the CIRP, 2, 27, pp. 583-589.

[13] PETERS, J., VANHERCK, P., VAN BRUSSEL, H. (1972). The Measurement of the Dynamic Cutting Coefficient. CIRP Annals, 2, 21.

[14] GOEL, B. S. (1976). Measurement of Dynamic Cutting Force Coefficients. A Thesis for the Degree of Ph. D.Hamilton: McMaster University. 
[15] RAO, S. B. (1977). Analysis of Dynamic Cutting Force Coefficient. A Thesis for the Degree of Ph. D. Hamilton: McMaster University.

[16] TlUSTY, J., MORIWAKI, T., GOEL, B. S. (1976). The Dynamic Cutting Coefficient for Some Carbon Steels, Proc. 4th NAMR Conf., Battelle's Labs, Columbus.

[17] JEMIELNIAK, K. (1992). Modeling of Dynamic Cutting Coefficients in Three-Dimensional Cutting. Int. J. Mach. Tools Manufacturing, August, 4, 32, pp. 509-519.

[18] KALS, H. J. J. (1971). On the Calculation of Stability Charts on the Basis of the Damping and Stiffness of the Cutting Process. CIRP Annals, 19, pp. 297-303.

[19] KNIGHT, W. A. (1972).Chatter in Turning: Some Effects of Tool Geometry and Cutting Conditions. Int. J. Machine Tool Design and Research, 3, 12, pp. 201-220.

[20] LIU, C. R., LIU, T. M. (1985). Automated Chatter Suppression by Tool Geometry Control. Journal of Engineering for Industry, 2, 107, pp. 95-100.

[21] SISSON, T. R., KEGG, R., L. (1969). An Explanation of Low Speed Chatter Effects. Journal of Engineering for Industry, November, 4, 91, pp. 951-958.

[22] BACH, P. (2012). Vibrace při obrábění. Machining \&Tooling Magazine, 3, pp. 1-5.

[23] MRKVICA, I., NESLUŠAN M., KONDERLA R., JURKO J., PANDA A., (2013). Cutting Forces by Turning of Incone 718 with Inserts frim Different Materials, Manufacturing Technology, Vol. 13, No. 4, pp. 499-504.

[24] CEP J., et al. (2013). Hard Machinable Machining of Cobalt/based Superalloy, Manufacturing Technology, Vol. 13, No. 2., pp. 142-147.

[25] KROLCZYK G., LEGUTKO S. (2013). The Machinability of Duplex Stainless Steel in Practice, Manufacturing Technology, Vol. 13, No. 2., pp. 473-478.

Paper number: M201401

Copyright @ 2014 . Published by Manufacturing Technology. All rights reserved. 